\title{
Molecular Identification and Genetic Characteristics of Genus Mystacoleucus Based on Gene Cytochrome Oxidase C Subunit I (COI) in Sengguruh Dam
}

\author{
Fitri Sil Valen ${ }^{1 *}$, Maheno Sri Widodo ${ }^{2}$, Yuni Kilawati ${ }^{3}$ \\ ${ }^{1}$ Graduate School of Fisheries and Marine Sciences, University of Brawijaya, Malang, Indonesia \\ ${ }^{2}$ Department of Aquaculture, Faculty of Fisheries and Marine Science, University of Brawijaya, Malang, Indonesia \\ ${ }^{3}$ Department of Aquatic Resources Management, Faculty of Fisheries and Marine Science, University of Brawijaya, \\ Malang, Indonesia
}

\begin{abstract}
In general, the process of naming several species of fish including species from the genus Mystacoleucus is still carried out based on morphological characters, which are often found in almost the same morphological characters in different fish species. Therefore, it is necessary to apply a more accurate identification method, which is a DNA-based identification method called DNA barcoding. The purpose of this study was to identify the species of the genus Mystacoleucus on the Sengguruh Dam molecularly based on the Cytochrome Oxidase C Subunit I (COI) gene. A caudal fin was taken on the test fish and preserved in $95 \%$ ethanol solution for molecular identification. The results of the identification showed that the sample belonged to the Mystacoleucus marginatus species with Identity values between 99-100\% and E-value 0.0 . The data obtained showed that from the calculation of genetic distance presented in the form of data matrix and phylogenetic tree reconstruction, there were 2 species that had a far genetic distance from the $M$. marginatus sample from the Sengguruh Dam namely M. atridorsalis with the furthest genetic distance of 0.1932-0.2595 and $M$. lepturus with genetic distance between $0.1117-0.1193$. However, there is one species that has the closest distance, M. padangensis with genetic distance between $0.0019-0.0038$ and identity values up to $99 \%$.
\end{abstract}

Keywords: DNA barcode, Molecular identification, Mystacoleucus, Phylogenetic COI.

\section{INTRODUCTION}

Indonesia has a very large diversity of freshwater fish. Found as many as 1218 species from 84 families including 1172 native species of 79 families and 630 species are endemic [1]. One of the endemic fish that lives in Indonesia is the Mystacoleucus genus. The genus Mystacoleucus is a family of Cyprinidae [2-5] with specific characteristics that have horizontal spines in front of the dorsal fin [1]. These fish live in tropical rivers $[6,7]$ and are spread throughout most of Asia [8-24].

Search results in FishBase and Catalog of Fishes found eleven species from the Mystacoleucus genus, and two of them were found in Indonesia, namely Mystacoleucus marginatus Valenciennes $1842[25,26,27]$ and Mystacoleucus padangensis Bleeker 1852 [1,24]. Apart from Indonesia, Mystacoleucus marginatus is also found in Malaysia [28], Thailand [5] and China $[29,30]$.

In general, the naming of several fish species including the genus Mystacoleucus is still based

\footnotetext{
* Correspondence address:

Fitri Sil Valen

Email : fitrisilvalen17@gmail.com

Address : Faculty of Fisheries and Marine Sciences, University of Brawijaya, Veteran Malang, Malang 65145.
}

on morphological characters [1]. It is quite difficult to ensure the naming of species because there are so many fish that look visually similar but are genetically different, and vice versa. For this reason, it is necessary to apply a method that is more accurate in identifying species and names. Along with the development of molecular biology, a new method has been found for identification of DNA-based species known as DNA Barcoding [31].

DNA barcoding provides speed and accuracy in species identification with a focus on analysis in small segments of mtDNA [32,33]. DNA barcoding can be a solution to the current taxonomic crisis [34] and has been developed to identify species because it is relatively easy to do compared to other techniques [35]. The use of DNA Barcoding can be practically applied [36] or as a tool to support other studies [37] by selecting one or several loci that can be routinely sequenced and can be relied upon to identify large numbers of samples and diverse and easy compared between species.

The current study showed that the partial COI gene sequence of fin clips and muscle tissue can be used as a diagnostic molecular marker for identification and resolution of taxonomic ambiguity of Ompok species [38]. Other study showed that the genes of cytochrome oxidase 
subunit I (COI) contained in mitochondria as DNA Barcoding globally have been chosen as standard tools for molecular taxonomy and animal identification [31]. The COI gene is a region that encodes a protein with a base length of up to 1551 starting from the start codon "GTG" and ending with the stop codon "TAA" in line 54897039 in mitochondrial DNA (mtDNA) [39].

This study aims to identify species and determine the genetic characteristics of the genus Mystacoleucus found in Sengguruh Dam, Malang. with a genetic approach based on the cytochrome oxidase c subunit I (COI) gene, so that it can confirm further molecular naming.

\section{MATERIALS AND METHODS}

\section{Sample Collection}

A total of five samples were collected from the Sengguruh Dam, Malang, East Java Province, from June to August 2018. For the purposes of molecular identification, a caudal fin was taken on the test fish and preserved in 95\% ethanol solution. Whereas as a reference for identification, a total of nine genus Mystacoleucus from various regions were downloaded from GenBank with accession numbers which can be seen in Table 1.

Table 1. DNA sequense of Genus Mystacoleuscus from Genbank

\begin{tabular}{llll}
\hline Spesies & Location & \multicolumn{2}{c}{ Accession Number } \\
\hline M. marginatus & Mojokerto & KU692639 & {$[27]$} \\
M. marginatus & Jawa barat & KU692643 & {$[27]$} \\
M. marginatus & Lumajang & KU692636 & {$[27]$} \\
M. marginatus & Malaysia & KT001017 & {$[28]$} \\
M. marginatus & Laos & JQ346160 & {$[40]$} \\
M. marginatus & China & KJ994653 & {$[30]$} \\
M. atridorsalis & Singapura & JF915630.1 & {$[41]$} \\
M. lepturus & China & KJ994654.1 & {$[30]$} \\
M. padangensis & Medan & MF062176.1 & {$[42]$} \\
\hline
\end{tabular}

DNA Extraction, Isolation, and Amplification

Genomic DNA extraction from all samples was carried out using the KIT method: Genomic DNA Mini Tissue Animal Kit (GENEAID). The Geneaid ${ }^{\text {TM }}$ DNA Isolation Kit offers a simple and gentle reagent DNA precipitation method for isolating high molecular weight genomic, mitochondrial or viral DNA suitable for archiving or sensitive downstream applications. This highly versatile solution based system can be scaled proportionately in order to satisfy larger sample volumes providing a convenient sample-storage procedure with minimal hands on time.

Initially, cells are lysed in the presence of detergents and a proprietary DNA stabilization solution followed by RNase A treatment. Once proteins and other contaminants are removed
DNA is precipitated then rehydrated. The high quality extracted DNA is ready for use in a variety of downstream applications. Amplification (PCR) of the mitochondrial locus cytochrome $c$ oxidase subunit I (COI) gene was carried out using the GO TAQ Green PCR Mix method with universal primary pairs LCO1490: 5'ggtcaacaaatcataaagatattgg-3' and HCO2198: 5' taaacttcagggtgaccaaaaaatca-3' [43]. Making mastermix (Go Taq Green) was carried out by adding $14 \mu \mathrm{L}$ ddH2O, forward and reverse primers of $2.5 \mu \mathrm{L}$, DMSO $1 \mu \mathrm{L}$, Go Taq Green 25 $\mu \mathrm{L}$ and DNA extraction of $5 \mu \mathrm{L}$. Amplification is carried out at a $50 \mu$ l final volume.

The PCR process includes pre-denaturation at $94^{\circ} \mathrm{C}$ for three minutes, followed by 35 cycles consisting of denaturation at $94^{\circ} \mathrm{C}$ for 30 seconds, annealing at $50^{\circ} \mathrm{C}$ for 30 seconds and extention stage at $72^{\circ} \mathrm{C}$ for 45 seconds. Furthermore, the PCR results were carried out by an electrophoresis process to separate, identify and purify DNA fragments, using $1 \%$ agarose gel with $50 \mathrm{mLTris}$ Borate EDTA (TBE). The PCR results that were successfully amplified were then sent to First Base CO (Malaysia) using Big Dye (C) terminator chemistry (Perkin Elmer), to obtain base arrangements that form DNA or nucleotide sequences.

\section{Data Analysis}

Sequencing results are aligned using the Clustal W method found in MEGA 6.06 software [44]. The sequential data is then matched with the data available in the NCBI GenBank (National Center for Biotechnology Information) online using the BLAST (Basic Local Alignment Search Tool-nucleotide) method. Genetic distance analysis of COI gene sequences was calculated using the pairwise distance method found in the MEGA 6.06 program [44]. The results of the calculation of genetic distance are presented in the form of a data matrix that can be used to analyze kinship relationships between species based on the tree of phylogeny. Phylogenetic reconstruction using the Maximum Likelihood Trees method [45], Kimura-2 parameter model and $10000 \times$ bootstrap value using MEGA 6.06 software [44].

\section{RESULTS AND DISCUSSION}

Species Identification

The length of the sequence results of the COI gene genus Mystacoleucus sequencing from the Sengguruh Dam using primers LCO1490 and HCO2198 is 683-686 bp (base pairs). The primary use of LCO1490 and HCO2198 [43]. The results 
show that the primary pairs of LCO1490 and HCO2198 consistently strengthen the fragments of approximately $700 \mathrm{bp}$. This result is also in accordance with the research conducted before [27-30,40,41] on the genus Mystacoleucus using the mitochondrial $\mathrm{COI}$ gene resulting in a sequence length of 549-859 bp. Some length differences in DNA sequences amplified due to the type of primer used, primary base composition, primary length, DNA quality found, food, offspring and environment [46]. A previous study suggested that $658 \mathrm{bp}$ fragments using the COI gene could be used as a differentiating basis between animals [31].

Samples from the Sengguruh Dam were then identified in Genbank using the BLAST method. Samples were identified as Mystacoleucus marginatus with query cover values between 95$98 \%$, Identity values between $99-100 \%$ and Evalue 0.0 . Based on the results of the BLAST analysis, it can be concluded that the sample DNA sequences have a very high level of similarity with the DNA sequences in GenBank. Wahyuningsih [47] suggested that with a similarity rate of $99-100 \%$ it could be said that species were identical and could be identified as that species. Claverie and Notredame [48] suggest that DNA sequences can be said to have homology if the E-value is smaller than e-0.4. The results of the identification are presented in Table 2.

\section{Genetic Characterisics}

Nucleotide analysis is very much needed in research because it is a compiler of DNA sequences. Nucleotides are DNA monomers containing three different parts, namely pentose sugar, nitrogen bases $(A, T, G, C)$ and phosphate groups [49]. The results of the analysis of nucleotide composition showed that the average amount of adenine and thymine was found to be the highest. The average nucleotide composition (Table 4) found in the COI M. marginatus gene in Sengguruh Dam is C (Cytosine) of $28.6 \%, T$ (Thymine) of $27.0 \%$, A (Adenine) of $27.6 \%$ and $G$ (Guanine) of $16.8 \%$. The $\mathrm{G}+\mathrm{C}$ content of all samples is $45.4 \%$ and has a lower number than the number of $A+T$ which amounts to $54.6 \%$.

Based on the nucleotide base composition, the nucleotide base of $M$. marginatus is dominated by alkaline $A$ (adenine) and $T$ (thymine) bonds so that the $\mathrm{CO}$ gene of both species is categorized as a rich A-T (A-T rich) group. The hydrogen bond $A-T$ consists of 2 hydrogen bonds which are weaker than the G-C hydrogen bonds which have 3 hydrogen bonds. The nucleotide base composition of Mystacoleucus marginatus is an easily separated bond so the possibility of mutation of species is higher. The composition of the nucleotide bases is presented in Table 3.

\section{Genetic distance and phylogenetic analysis}

The genetic distance of the COI gene fragment between Mystacoleucus spp. based on research results and GenBank is presented in the form of a data matrix (Table 4). The genetic distance of interspecific $M$. marginatus ranges from $0.0000-0.0625$. While the highest genetic distance of intraspecies Mystacoleucus spp was found in $M$. atridorsalis of 0.2595 , then $M$. lepturus and $M$. padangensis for 0.1193 and 0.0038 respectively.

Data from the genetic distance matrix on COI gene fragments were used to analyze kinship relationships based on the phylogeny tree. The phylogenetic reconstruction based on the COI gene using the Maximum Likelihood Trees method of the Kimura-2 parameter and the bootstrap value 10000 is shown in Figure 1.

Table 2. The results of the identification of the Genus Mystacoleucus sequences in the Sengguruh Dam through BLAST Analysis

\begin{tabular}{cccccc}
\hline \multirow{2}{*}{ Sample code } & \multirow{2}{*}{ Species outcome } & \multicolumn{4}{c}{ BLAST } \\
\cline { 3 - 5 } & & Access code of NCBI & Query Cover(\%) & E-value & Identity (\%) \\
\hline BS $^{1}$ & M. marginatus & KU692642.1 & 95 & 0.0 & 100 \\
$\mathrm{BS}^{2}$ & M. marginatus & KU692641.1 & 95 & 0.0 & 100 \\
$\mathrm{BS}^{3}$ & M. marginatus & KT001063.1 & 98 & 0.0 & 99 \\
\hline
\end{tabular}

Table 3. Composition of Nucleutide bases Mystacoleucus marginatus in the Sengguruh Dam

\begin{tabular}{ccccc}
\hline \multirow{2}{*}{ Sample code } & \multicolumn{3}{c}{ Nucleotides } \\
\cline { 2 - 5 } & T (Thymine) & C (Cytosin) & A (Adenin) & G (Guanine) \\
\hline $\mathrm{BS}^{01}$ & 27.0 & 28.7 & 27.6 & 16.7 \\
$\mathrm{BS}^{02}$ & 26.8 & 28.7 & 27.7 & 16.8 \\
$\mathrm{BS}^{03}$ & 27.3 & 28.5 & 27.5 & 16.7 \\
\hline Average & 27.0 & 28.6 & 27.6 & 16.8 \\
\hline
\end{tabular}


Table 4. Genetic distance of Mystacoleucus spp.

\begin{tabular}{|c|c|c|c|c|c|c|c|c|c|c|c|}
\hline & 1 & 2 & 3 & 4 & 5 & 6 & 7 & 8 & 9 & 10 & 11 \\
\hline \multicolumn{12}{|l|}{$\mathrm{BS}^{01}$} \\
\hline $\mathrm{BS}^{02}$ & 0.0000 & & & & & & & & & & \\
\hline BS $^{03}$ & 0.0019 & 0.0019 & & & & & & & & & \\
\hline Mojokerto & 0.0000 & 0.0000 & 0.0019 & & & & & & & & \\
\hline Lumajang & 0.0000 & 0.0000 & 0.0019 & 0.0000 & & & & & & & \\
\hline Jawa_Barat & 0.0019 & 0.0019 & 0.0057 & 0.0019 & 0.0019 & & & & & & \\
\hline Malaysia & 0.0057 & 0.0057 & 0.0133 & 0.0057 & 0.0057 & 0.0057 & & & & & \\
\hline China & 0.0625 & 0.0625 & 0.0795 & 0.0625 & 0.0625 & 0.0436 & 0.0473 & & & & \\
\hline Laos & 0.0625 & 0.0625 & 0.0795 & 0.0625 & 0.0625 & 0.0436 & 0.0473 & 0.0000 & & & \\
\hline M. padangensis & 0.0038 & 0.0038 & 0.0095 & 0.0038 & 0.0038 & 0.0019 & 0.0019 & 0.0398 & 0.0398 & & \\
\hline M. lepturus & 0.1193 & 0.1193 & 0.1420 & 0.1193 & 0.1193 & 0.1117 & 0.0758 & 0.0852 & 0.0852 & 0.0852 & \\
\hline M. atridorsalis & 0.2595 & 0.2595 & 0.2973 & 0.2595 & 0.2595 & 0.2367 & 0.1932 & 0.1269 & 0.1269 & 0.2027 & 0.0417 \\
\hline
\end{tabular}

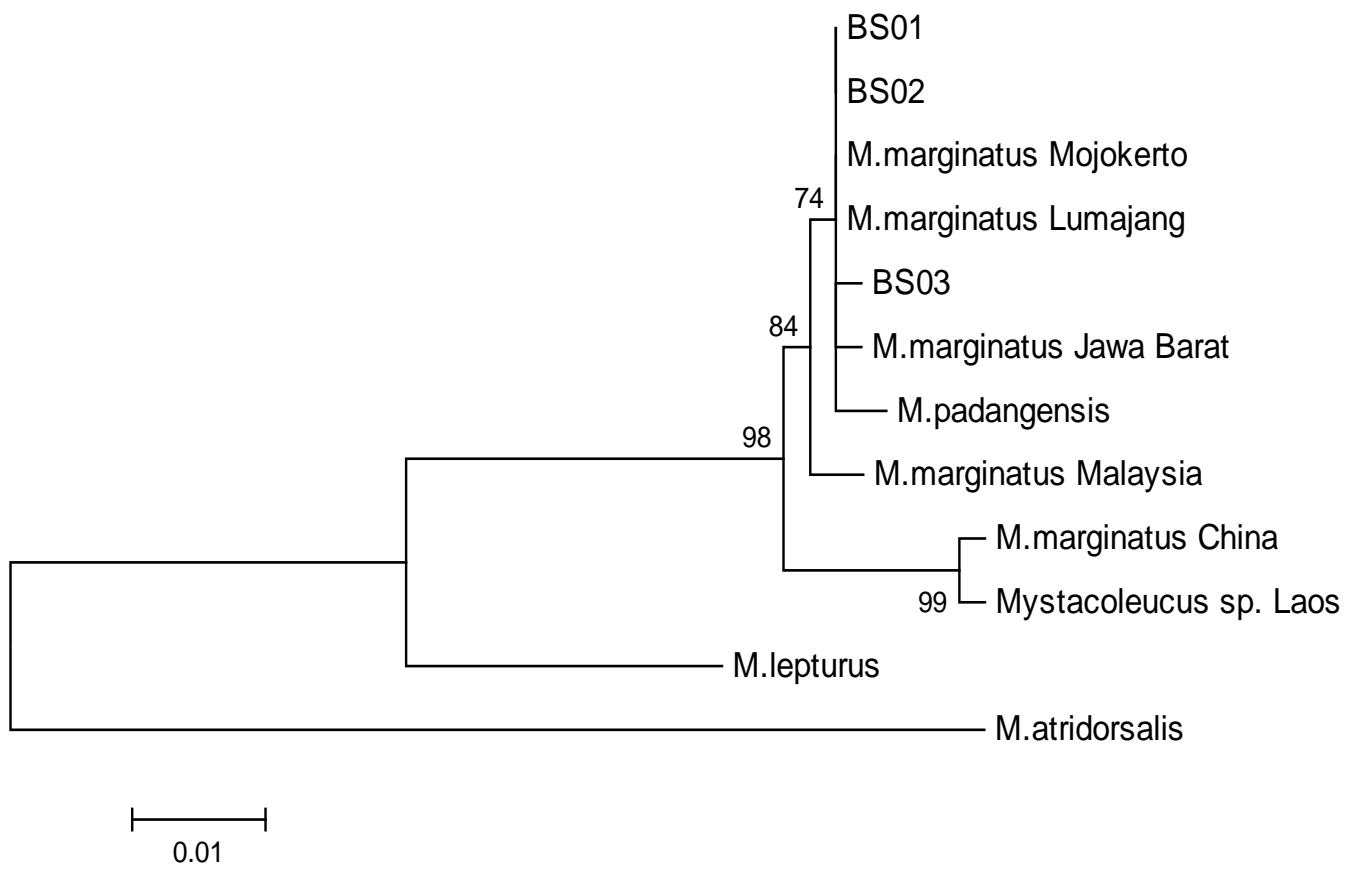

Figure 1. Phylogenetic reconstruction of Mystacoleucus spp. based on cytochrome oxidase c subunit I (COI) Gene

The construction of the phylogeny tree based on the COI gene above shows that the species in the $M$. marginatus group are significantly different from the $M$. atridorsalis species with genetic distances of 0.1932-0.2595 and $M$. lepturus with a genetic distance between 0.1117 0.1193 . Genetically M. marginatus is very close to $M$. padangensis, the genetic distance of these two species ranges from $0.0019-0.0038$. This is also proven by the results of BLAST, where the samples identified as $M$. marginatus from the Sengguruh Dam have an Identity value of $99 \%$ and E-value 0.0. with $M$. padangensis, so it can be concluded that the DNA sequences of $M$. marginatus and $M$. padangensis have very high genetic similarities. Wahyuningsih [47] suggested that with a $99-100 \%$ similarity rate it could be said that the species was identical and DNA sequences had homology if the E-value was smaller than e-0.4 [48].

Based on the phylogenetic tree reconstruction, it was also seen that by ingroup species, individuals of different $M$. marginatus distribution regions had very close relationships with genetic distances between 0.0625-0.0000, where 0.000 is the closest distance and this value indicates that from 1000 base pairs, no one has a different base pair. The closest distance is obtained by the $M$. marginatus species from Sengguruh Dam, Mojokerto and Lumajang. Mojokerto has a genetic closeness with the Sengguruh Dam because it is still in one water source, namely Brantas waters, from Mount Arjuno springs, Brantas source village, Bumi Aji District, Batu City which then flows to Malang, Blitar, Kediri, Mojokerto, and Sidoarjo. This 
pattern of currents results in gene flow or gene exchange between locations resulting in homogeneous genes.

It is also known that the spread of $M$. marginatus is very broad covering the territory of Indonesia (East Java and West Java) to Malaysia, Laos, and China. This spread is possible due to the influence of Sundaland, where the Sunda region has a shallow continental shelf and changes in the eustatic sea repeatedly linking large islands in this region (Sundanese and Southeast Asian exposures) form Sundaland $[16,50]$. This allows the migration of freshwater fish into and outside Java which may have occurred 10-70 thousand years ago [51].

\section{CONCLUSION}

The length of fragments from the amplification of the COI gene of the genus Mystacoleucus from the Sengguruh Dam using primary LCO1490 and HCO2198 is 681-686 bp (base pairs), which shows that the test sample belongs to the $M$. marginatus species with an identity value of $99-100 \%$ and E-value 0.0 . The average nucleotide composition in the COI $M$. marginatus gene in Sengguruh Dam is $C$ (Cytosine) of $28.6 \%, \mathrm{~T}$ (Thymine) of $27.0 \%, \mathrm{~A}$ (Adenine) of $27.6 \%$ and $G$ (Guanine) of $16.8 \%$. The $\mathrm{G}+\mathrm{C}$ content of all samples is $45.4 \%$ and has a lower number than the number of $A+T$ which amounts to $54.6 \%$.

\section{REFERENCES}

[1] Kottelat, M., A.J. Whitten, S.R. Kartikasari, S. Wirjoatmodjo. 1993. Freshwater fishes of western Indonesia and Sulawesi. Periplus Editions. Singapore.

[2] Roberts, T.R. 1993. The freshwater fishes of Java, as observed by Kuhl and van Hasselt in 1820-23. Zoologische Verhandelingen (Leiden). 285. 1-94.

[3] Vidthayanon, C. 2012. Mystacoleucus argenteus. The IUCN Red List of Threatened Species 2012. IUCN.

[4] Rainboth, W. 2012. Mystacoleucus ectypus. The IUCN Red List of Threatened Species 2012. IUCN.

[5] Kottelat, M. 2013. The fishes of the inland waters of Southeast Asia: a catalogue and core bibiography of the fishes known to occur in freshwaters, mangroves and estuaries. Raffles Bull. Zool. 27. 1-663.

[6] Nelson, J.S. 2006. Fishes of the world, $4^{\text {th }}$ Ed. John Wiley and Sons, Inc.
[7] Froese, R., D. Pauly (Eds). 2014. FishBase. World Wide Web electronic publication. www.fishbase.org, version (08/2013).

[8] Bertin, L., R. Estève. 1948. Catalogue des types de poissons du Muséum National d'Histoire Naturelle. 4e partie. Ostariophysaires (Cypriniformes). Imp. Nationale, Paris. 4e. 1-117.

[9] Monkolprasit, S.P. 1969. Type specimens of Thai cyprinoid fishes. Kasetsart Univ. Fish. Res. Bull. 5. 1-16.

[10] Whitehead, P.J.P., P.K. Talwar. 1976. Francis Day (1829-1889) and his collections of Indian fishes. Bull. Br. Mus. Nat. Hist. Hist. 5(1). 1-189, Pls. 1-4.

[11] Böhlke, E.B. 1984. Catalog of type specimens in the ichthyological collection of the Academy of Natural Sciences of Philadelphia. Special Publication, Acad. Nat. Sci. Phila. 14(i-viii). 1-216.

[12] Kottelat, M. 1984. A review of the species of Indochinese fresh-water fishes described by H.E. Sauvage. Bull. Mus. Natl. Hist. Nat. Ser. 4: Section A: Zoologie, Biologie et Écologie Animales. 6(4). 791-822.

[13] Roberts, T.R. 1989. The freshwater fishes of western Borneo (Kalimantan Barat, Indonesia). Mem. Calif. Acad. Sci. 14(i-xii). 1210.

[14] Lim, K.K.P., P.K.L. Ng, M. Kottelat. 1990. On a collection of freshwater fishes from Endau-Rompin, Pahang-Johore, Peninsular Malaysia. Bull. Raffles Mus. 38(1). 31-54.

[15] Kottelat, M., K.K.P. Lim. 1995. Freshwater fishes of Sarawak and Brunei Darussalam: a preliminary annotated check-list. Sarawak Mus. J. (New Series). 48(69). 227-256.

[16] Rainboth, W.J. 1996. The taxonomy, systematics and zoogeography of Hypsibarbus, a new genus of large barbs (Pisces, Cyprinidae) from the rivers of Southeastern Asia. University of California Press, La Jolla.

[17] Doi, A. 1997. A review of taxonomic studies of cypriniform fishes in Southeast Asia. Jpn. J. Ichthyol. 44(1). 1-33.

[18] Kottelat, M. 1998. Fishes of the Nam Theun and Xe Bangfai basins, Laos, with diagnoses of twenty-two new species (Teleostei: Cyprinidae, Balitoridae, Cobitidae, Coiidae and Odontobutidae). Ichthyol. Explor. Fres. 9(1). 1-128.

[19] Ng, H.H., H.H. Tan. 1999. The fishes of the Endau drainage, Peninsular Malaysia with descriptions of two new species of catfishes 
(Teleostei: Akysidae, Bagridae). Zool. Stud. 38(3). 350-366.

[20] Kottelat, M. 2000. Diagnoses of a new genus and 64 new species of fishes from Laos (Teleostei: Cyprinidae, Balitoridae, Bagridae, Syngnathidae, Chaudhuriidae and Tetraodontidae). J. South Asian Nat. Hist. 5(1). 37-82.

[21] Le, P.Q., Y.Y. Chen. 2000. Fauna sinica, osteichthyes, cypriniformes III. Science Press. Beijing.

[22] Kottelat, M. 2001. Fishes of Laos. WHT Publications, Colombo. 1-198, Pls. 1-48.

[23] Kottelat, M. 2015. The fishes of the Nam Theun and Xe Bangfai drainages, Laos. Hydroécol. Appl. (Paris). 19. [1-51]. 271-320.

[24] Nofrita., Dahelmi., H. Syandri, D.H. Tjong. 2015. Morphological differentiation between Bilih Fish (Cyprinidae: Mystacoleucus padangensis, Blekeer) in Singkarak Lake and Anai River, West Sumatra, Indonesia. J. Entomol. Cool. Stud. 3(5). 171-175.

[25] Freyhof, J., D.V. Serov, T.N. Nguyen. 2000. A preliminary checklist of the freshwater fishes of the River Dong Nai, South Vietnam. Bonner Zoologische Beiträge. 49(1-4). 93-99.

[26] Kottelat, M., E. Widjanarti. 2005. The fishes of Danau Sentarum National Park and the Kapuas Lakes area, Kalimantan Barat, Indonesia. Raffles Bulle. Zool. 13. 139-173.

[27] Dahruddin, H., A. Hutama, F. Busson, S. Sauri, R. Hanner, P. Keith, R. Hadiaty, N. Hubert. 2017. Revisiting the ichthyodiversity of Java and Bali through DNA barcodes: taxonomic coverage, identification accuracy, cryptic diversity and identification of exotic species. Mol. Ecol. Resour. 17(2). 288299.

[28] Meganathan, P., C.M. Austin, S.M. Tam, P.C. Chew, R. Siow, Z. Abdul Rashid, B.K. Song. 2015. An application of DNA barcoding to the Malaysian freshwater fish fauna: mtDNA COI sequences reveal novel haplotypes, cryptic species and field-based misidentification. Monash University Malaysia. Selangor, Malaysia.

[29] Yang L., T. Sado, M.V. Hirt, E.P. Viel, M. Arunachalam, X. Wang, J. Freyhof, K. Saitoh, A.M. Simons, M. Miya, R.L. Mayden, J. Li, S. He, R.L. Mayden. 2015. Phylogeny and polyploidy: Resolving the classification of cyprinine fishes (Teleostei: Cypriniformes). Mol. Phylogenetics Evol. 85. 97116.
[30] Zheng, L.P., J.X. Yang, X.Y. Chen. 2016. State Key Laboratory of Genetic Resources and Evolution, Kunming Institut of Zoology, Chinese Academi of Sciences, 32 Jiaochang Donglu, Yunan 650223, China. Biochem. Syst. Ecol. 68. 250-259.

[31] Hebert, P.D.N., A. Cywinska, S.L. Ball. 2003. Biological identifications through DNA barcodes. Proc. Royal Soc. London. Series B: Biol. Sci. 270(151). 313-321.

[32] Muchlisin, Z.A., Z. Thomy, N. Fadli, M.A. Sarong, M.N. Siti-Azizah. 2013. DNA barcoding of freswater fishes from Lake Laut Tawar, Aceh Province, Indonesia. Acta Ichtyiol. Piscat. 43(1). 21-29.

[33] Karim, A., A. Iqbal, R. Akhtar, M. Rizwan, A. Amar, U. Qamar, S. Jahan. 2015. Barcoding of fresh water fishes from Pakistan. Mitochondrial DNA. 1-4.

[34] Meier, R., K. Shiyang, G. Vaidya, K.L.N. Peter. 2006. DNA barcoding and taxonomy in Diptera. A tale of high intraspesific variability and low identification success. System Bio. 55. 715-728.

[35] Woong, L.L., Peatman., J. Lu, H. Kucuktas, S. He, Ch. Zhou, U. Nanacorn. Z. Liu. 2011. DNA barcoding of catfish: species authentication and phylogenetic assessment. PloS ONE. 6. e17812.

[36] Stocle, M.Y., C.C. Gamble, R. Kirpekar, G. Young, S. Ahmed, D.P. Little. 2011. Comercials teas highlight plant DNA Barcode identification succeces and obstaclesses and obstacles. Sci. Rep. I(42). 1-7.

[37] Ebihara, A., J.H. Nitta, M. Ito. 2010. Molecular species identification with rich floristic sampling: DNA barcoding the pteridophyte flora of Japan. Plos ONE. 5(12). e15136.

[38] Malakar, A.K., Lakra, W.S. Goswami, M. Singh, R.M. Mishra. 2012. Molecular identification of threeOmpokspecies using mitochondrial $\mathrm{COI}$ gene. Mitochondrial DNA. 23(1). 20-24.

[39] Liu, S., Yang, Z., Wang, D. dan Liu, M. 2014. The mitochondrial genome of Mystacoleucus marginatus (Cypriniformes, Cyprinidae). Mitochondrial DNA.

[40] Pasco-Viel, E., M. Veran, L. Viriot. 2012. Revision of the genus Cyclocheilichthys (Bleeker 1859) and resurrection of the genus Anematichthys (Bleeker 1859), based on morphological and molecular data of 
Southeast Asian Cyprininae (Teleostei, Cypriniformes). Zootaxa. 3586. 41-54.

[41] Collins, R.A., Y. Yi, R. Meier, K. Armstrong. 2016. Barbs, barcodes and biosecurity: identifying ctprinid fishes in the ornamental trade. Unpublished

[42] Wibowo, A., S. Kaban. 2017 Genetic diagnosis and reproductive biology of translocated Mystacoleucus padangensis in the Toba Lake, North Sumatra. Unpublished.

[43] Folmer O., Black M., Hoeh W., Lutz R., and Vrijenhoek R. 1994. DNA primers for amplification of mitochondrial cytochrome $\mathrm{c}$ oxidase sub unit I from diverse metazoan invertebrates. Molecular Marine Biology and Biotechnology 3(5) : 294-299.

[44] Tamura, K., D. Peterson, N. Peterson, G. Stecher, M. Nei, S. Kumar. 2011. MEGA5: Molecular evolutionary genetics analysis using maximum likehood, evolutionary distance and maximum parsimony method. Mol. Biol. Evol. 28(10). 2731-2739.

[45] Lemey, P., M. Salemi, A.M. Vandamme (Eds). The Phylogenetic handbook: a practical approach to phylogenetic analysis and hypothesis testing. Cambridge University Press. New York. 419-490.

[46] Shizuka, D., B.E. Lyon. 2008. Improving the reliability of molecular sexing using a Wspecific marker. Mol. Ecol. Resour. 8. 1249-1253.

[47] Wahyuningsih. 2013. Parameter populasi ikan kakap merah (Lutjanus malabaricus) di perairan laut Jawa bagian timur. Balai Perikanan Laut Jakarta. 5(3). 175-179.

[48] Claverie, J., C. Notredame. 2003. Bioinformatics for dummies. Wiley Publishing Inc. New York. 325.

[49] Blanco, A., B. Gustavo. 2017. Chapter 6 medical biochemistry. Academic Press. 121140.

[50] Voris, H.K. 2000. Maps of Pleistocene sea levels in Southeast Asia: shorelines, river systems and time durations. J. Biogeogr. 27. 1153-1167.

[51] Kusuma, W.E., S. Ratmuangkhwang, Y. Kumazawa. 2016. Department of Information and Basic Science and Research Center for Biological Diversity, Department of Aquaculture, Faculty of Fisheries and Marine Science, University of Brawijaya, Andaman Coastal Research Station for Development, Faculty of Fisheries, KU. 